\title{
Sense of professional agency in ELT practicum: Comparison of Polish, Portuguese, and Turkish contexts
}

\author{
Burçak Yılmaz Yakışık ${ }^{\text {* }}$ (i) , Fatıma Nur Fişne ${ }^{\text {b (iD) }}$, Gonca Yangın Ekşi ${ }^{c}$ \\ "Gazi University, School of Foreign Languages, Ankara, 06800, Turkey \\ ${ }^{b}$ Gazi University, Gazi Faculty of Education, Department of English Language Teaching, Ankara, 06500, Turkey \\ APA Citation: \\ ${ }^{c}$ Gazi University, Gazi Faculty of Education, Department of English Language Teaching, Ankara, 06500, Turkey
}

Yakışık, B.Y., Fişne, F.N., \& Ekşi, G.Y. (2019). Sense of professional agency in ELT practicum: Comparison of Polish, Portuguese, and Turkish contexts. Journal of Language and Linguistic Studies, 15(4), 1317-1331.

Submission Date:.10/09/2019

Acceptance Date:.4/11/2019

\begin{abstract}
Teacher agency is a concept that defines a teacher's commitments and capabilities of making decisions and taking actions which result in a change in the community of teaching (Husu \& Toom, 2010; Pietarinen, Pyhälto \& Soini, 2016). Since practicum teaching is the first place where teacher trainees enhance both theoretical and practical teaching experiences, it plays a crucial role in shaping teacher trainees' professional agency. Putting emphasis on the practicum teaching and different instructional backgrounds, this study aims to describe English language teacher trainees' sense of professional agency in practicum in Poland, Portugal, and Turkey. In addition, it attempts to compare three practicum settings in terms of the professional agency. The main findings of the study show that teacher trainees have a sense of professional agency in three countries but their level of agency varies. Considering the dynamics of agency, it can be stated that teacher trainees feel more agentic in reflection. Turkish and Portuguese practicum contexts show similarities in the components of reflection and positive interdependence; however, three countries significantly differ in the sense of professional agency from a holistic perspective.
\end{abstract}

(C) 2019 JLLS and the Authors - Published by JLLS.

Keywords: teacher trainees' agency; practicum; comparison of professional agency

\section{Introduction}

The integrative concept, professional teacher agency, reflects teachers' capability of taking active roles in their work communities. The multifaceted face of professional agency determines teachers to be active agents in various ways such as assuring responsibility, collaborating, providing help, developing professionally (Eteläpelto, Vähäsantanen, Hökkä, \& Paloniemi, 2013; Soini, Pietarinen, \& Pyhälto, 2016, Pyhältö, Pietarinen, \& Soini, 2015). However, the capacity of teachers to attain active roles as regards their profession substantially depends on the different phases of their teaching career, different implementations at teacher education and influences at their multiple educational policy contexts (Toom, Pyhältö, \& Rust, 2015). To this end, teacher trainees' capability of developing a sense of professional agency has been investigated in this research within a comparative framework. Three

\footnotetext{
${ }^{*}$ Corresponding author.

E-mail address: burcak@gazi.edu.tr
} 
different practicum teaching settings, namely Polish, Portuguese, and Turkish contexts, were selected in consideration of the geographical locations and OECD reports (2018) that indicate differences in the educational status of these three countries.

The diversity in the parameters that affect professional teacher agency will shed light onto the investigation of multifaceted professional agency formation. Very few studies have investigated the teacher trainees' sense of professional development and the restricting and strengthening effects of practicum teaching (Eröz-Tuğa, 2012; Susoy, 2015; Turnbull, 2005). However, studies reveal that practicum teaching is the first authentic context where teacher trainees are confronted with the real students and the work community. It is the place where they attempt to bridge the gap between teacher education and classroom realities for the first time (Eröz-Tuğa; 2013; Susoy, 2015). It is also remarkable to note that the implementation of practicum teaching varies according to the educational policies of the countries. Each practicum teaching is assumed to have a restricting and positively affecting role on the development of teacher trainees' sense of professional development as they will confront various constraints and challenges as a result of provided resources and opportunities within their teaching context.

\subsection{Literature review}

\subsubsection{Professional teacher agency}

The literature describes the notion of "agency" as one's commitment and capability to make choices and take intentional actions in a way that results in difference in one's life and in community (Pyhältö, Soini, \& Pietarinen, 2011; Pyhältö, Pietarinen, \& Soini, 2014; 2015; Vähäsantanen, Saarinen, \& Eteläpelto, 2009). The concept of professional teacher agency involves personal, situational and social parameters which construct teachers' agentic behaviours. These parameters might be the support or constraints in the workplace, professional relationships in the school community, leadership and organizational climate (Clement \& Vanderberghe, 2000; Vähäsantanen et al., 2009).

There are some studies that focus on teacher development at certain points in a teacher's career (Lipponen \& Kumpulainen, 2011; Zeichner \& Conklin, 2010); nevertheless, there are fewer studies focusing on how and in what forms teacher learning occurs in the everyday practices of school (Hoekstra, Beijard, Brekelmans, \& Korthagen, 2007). Moreover, the tendency in recent teacher education research is to investigate a particular element of teacher learning such as reflective practice (Akbari, 2007; Husu, Toom, \& Patrkainen, 2008); teacher beliefs (De Vries, Jansen, \& Van de Grift, 2013); and teacher motivation (Han \& Yin, 2016). There are some studies that reveal that teacher learning is a multidimensional phenomenon that cannot be attributed to one concept (Meirink, Meijer, Verloop, \& Bergen, 2009). However, there is still scarcity in the investigation of interrelation between teacher learning in the professional community and classroom practices (Pietarinen, Pyhältö, \& Soini, 2016). The need to describe the multi-dimensional feature of teacher learning is confronted by the concept of 'professional agency' as it entails several notions related to teacher learning such as teacher motivation as the individual teacher constitutes the will to learn; and teacher autonomy as the teacher regulates his/her own learning, professional development and beliefs (Sachs, 2003; Turnbull, 2005).

Some research basically focuses on different behavioural attributes teachers benefit from while reforming teaching and modifying instructional practices. Pietarinen, Pyhältö, and Soini (2016) describe constructing professional relationships and relying on them as collective efficacy, and constructing organizational climate as positive interdependence, both of which are the behavioural attributes at community level whereas reflecting on teacher experiences is at the individual level. 


\subsubsection{Behavioural attributes affecting professional teacher agency}

Professional agency is priorly defined as the capacity of the teachers to manage their own learning both as a personal endeavour and in the school community (Pyhältö, Pietarinen, Soini, 2012; Pyhältö et al., 2014; Pietarinen et al., 2016). In this sense, collective efficacy involves both using others in the community of school as a resource and acting as an aid for them, which Pietarinen et al. (2016) report as "co-regulative learning" (p. 114). It is a common belief among teacher practitioners that teachers are influenced by their working environment; however, they can also act as leaders to modify the working environment. Accordingly, professional agency refers to the teacher capacity to construct this conducive atmosphere for developing. For instance, effective teacher learning may occur in a teacher community where collaboration and mutual support are fostered. Furthermore, this context-dependent nature of teacher learning might result in instructional and educational reforms carried out by teachers (Pietarinen et al., 2016).

Some studies indicate that positive emotions evoked in the collegial environment promote efficient teacher learning since colleagues can rely on each other in a supportive organizational climate (Bakkanes, Vermunt, Wubbels, \& Imants, 2006; Pyhältö et al., 2014; 2015). There are more studies which report that mutual support among colleagues influences teachers' affective attributes. More particularly, teachers who get support from their colleagues are less likely to quit the profession (Pomaki, DeLongis, Frey, Short, \& Woerhle, 2010). The interrelation between collective efficacy, positive interdependence and reflective practice is remarkable, and it is noteworthy to state that the first two parameters at community level contribute to the third parameter at individual level. The study conducted by Pietarinen et al. (2016) shows that "experienced agency in the professional community contributed to teacher learning in the classroom" (p. 124). Some studies (Edwards, 2007; Lipponen \& Kumpulainen, 2011) also confirm that the teachers benefiting from positive interdependence in the professional community are more likely to enhance students' learning in the classroom as they expand their practical knowledge through reflection on their teaching practices.

Pre-service and in-service teachers' agentic behaviours might indicate diversity at the community and individual level. Skaalvik and Skaalvik (2011) yield that supervisory support contributes to collective efficacy, and supervisory support is found to be a significant dimension that constructs preservice teachers' agency particularly in practicum studies (Degago, 2007; Turnbull, 2005). Nonetheless, there are some contradictory studies among in-service teachers in this issue. Although Meirink et al. (2009) point out that in-service teachers confirm teacher learning by relying on their colleagues in solving problematic situations, Kwakman (2003) reports that in-service teachers rarely observe each other in class or get prepared for the lessons with a collaborative work in order to develop their teaching.

\subsection{Research questions}

In order to elaborate on the concept of the professional agency in pre-service teacher education programs, this study aims to describe and compare English language teacher trainees' sense of professional agency in practicum in three different countries, Poland, Portugal, and Turkey. The following research questions will throw light upon the description and comparison of the agency in practicum settings.

1. To what extent do English language teacher trainees have a sense of professional agency in practicum contexts in Poland, Portugal, and Turkey?

2. Is there a statistically significant difference among these three countries in terms of the teacher trainees' perceptions of professional agency in the practicum? 


\section{Method}

\subsection{Research design}

Within the framework of quantitative research methodology, descriptive research design has been used in this study. As the name suggests, descriptive research provides information about the specifics of the construct. According to Cohen, Manion and Morrison (2007), "such studies look at individuals, groups, institutions, methods and materials in order to describe, compare, contrast, classify, analyse and interpret the entities and the events that constitute their various fields of inquiry" (p. 205). From this perspective, the professional agency of teacher trainees in Poland, Portugal and Turkey has been described and compared through the administration of a questionnaire.

\subsection{Participants}

The subject group of this study consists of 90 English language teacher trainees who broaden teaching experiences in practicum in Poland $(n=27)$, Portugal $(n=21)$, and Turkey $(n=42)$. They were selected with convenience sampling which helps the researchers to collect data from the participants in more practical ways (Fraenkel, Wallen, \& Hyun, 2012). In the Turkish context, 32 participants (76.19\%) were female, and 10 participants were male $(23.81 \%)$. All of them were aged between 22 and 25 years. While 34 teacher trainees had their practicum at state secondary schools $(80.95 \%), 8$ teacher trainees practiced at state high schools $(19.05 \%)$. With respect to the research setting in Portugal, all participants were female $(n=21)$. Their age ranged from 22 to 55 years, and the mean age of the participants was 36 in Portugal. Their practicum schools were categorized as the basic, primary, secondary and high schools. As for the Polish context, the demographics show that 24 participants (88.89\%) were female, and 3 participants were male (11.11\%). Their age group was between 23 and 44 years.

\subsection{Practicum settings}

Practicum is an essential part of teacher education which gives opportunities to teacher trainees to get involved in the teaching community. In this study, there are three different practicum contexts. In Turkey, practicum takes place in the seventh and eighth semester of 4-year English language teaching program at the BA level. The first semester is called "School Experience", and teacher trainees observe language classrooms at state schools. In this term, teacher trainees have weekly meetings with teacher trainers about their observation. The second semester is "Teaching Experience", in which they have active roles in lesson planning, teaching language skills, material development, assessment and evaluation, and classroom management. During this semester, teacher trainers observe trainees' teaching skills in practicum settings, and give feedback on their strengths and weaknesses. In Poland, practicum may be offered in 3-year BA program for teacher trainees who will work in primary education or 2-year MA program for teacher trainees who will work in secondary education. In this research context, teacher trainees have three semesters of practicum. Firstly, they observe the instructional setting and reflect on what they have experienced. Then they give assistance to their mentor teachers in course preparation, material design and testing. Following that, they get prepared to teach on their own. Finally, they familiarize themselves with the documentation process. In Portugal, practicum is given at the MA level. If the MA program entitles teaching young learners, teacher trainees are educated for 3 semesters, but the programs for teaching upper levels last 4 semesters. As for the context of practicum, teacher trainees attend and observe the lessons at the beginning. In the following stages, they get involved in lesson planning and teaching. Besides, they have weekly meetings with their teacher trainers to discuss the practicum process. 


\subsection{Data collection}

In this study, quantitative data were collected through the 7 point Likert questionnaire with 3 main factors and 18 items. The questionnaire is entitled "Teacher Trainees' Sense of Professional Agency in Practicum" (TTSPAP). It has been adapted from the questionnaire of "Teachers' Sense of Professional Agency" which was developed by Pietarinen et al. (2016) in order to measure the teacher agency in inservice teaching. The adaptation of this questionnaire into practicum context has been carried out in accordance with the steps explained below:

a) The questionnaire items were re-written by English language teacher educators in line with the practicum practices and pre-service teacher education.

b) The questionnaire was piloted in a large sample $(\mathrm{N}=251)$ to conduct exploratory factor analysis (EFA) with the aim of ensuring the construct validity. As one of the requirements of the EFA, Kaiser-Meyer-Olkin (KMO) Test and Bartlett's Test of Sphericity were administered. The results show that chi-square value is statistically significant in Bartlett's test of sphericity ( $\chi 2$ $=1901.365, \mathrm{p}=.00<0.05)$, and the sample size is necessarily adequate $(\mathrm{KMO}=.88)$ to employ the EFA.

c) The results of the EFA show that the questionnaire was validated with 3 factors and 18 items. The factors are respectively given as follows according to the magnitude of the eigenvalues: Collective Efficacy, Reflection and Positive Interdependence. This factor structure explains $51.65 \%$ of the total variance.

d) Following the validation of the factor structure, reliability statistics were calculated to figure out how consistently the questionnaire items could measure the sense of professional agency. Cronbach Alpha value of the questionnaire was reported as .87. This indicates a high level of reliability according to Hinton, McMurray, and Brownlow (2014). Reliability analysis also explicates that the questionnaire items in each factor are internally consistent. "Collective Efficacy" $(\alpha=.84)$, "Reflection" $(\alpha=.77)$ and "Positive Interdependence" $(\alpha=.74)$ are viewed as the factors which consistently measure the target construct.

\subsection{Data analysis}

Quantitative data were analysed in SPSS 21 (Statistical Package for Social Sciences). First of all, descriptive statistics (e.g. mean scores, standard deviation) were used to provide information on the participants' levels of professional agency. Besides that, comparison tests were conducted to compare teacher trainees' sense of professional agency in three countries. In order to test the assumption of the comparison tests, normality tests were employed, and test results showed that some data sets were not normally distributed. Likewise, homogeneity of variance was not ensured in the data sets of the participants in three countries. For these reasons, non-parametric test, Kruskal-Wallis H Test, was conducted to explicate whether teacher trainees in three different countries vary in their sense of professional agency. Test results highlight statistically significant differences in some comparisons. To elaborate on these differences, Mann-Whitney $U$ test was employed to compare two countries in order to find the source of statistical difference. 


\section{Results}

This section presents data analysis results under the sections of the questionnaire factors. First of all, teacher trainees' professional agency in Poland, Portugal, and Turkey is comparatively described, and then these descriptive results are compared to understand whether there is a statistically significant difference among these countries in terms of the professional agency in practicum.

\subsection{Professional agency in practicum}

The mean scores and standard deviations of the total scores obtained from the questionnaire are summarized in Table 1. According to Table 1, English language teacher trainees in Portugal have the highest mean score $(M=115.24)$ when compared to other participants in Portugal and Turkey.

Table 1. Descriptive Statistics for PTSPAP Questionnaire (Total Scores)

\begin{tabular}{cccccccc}
\hline & \multicolumn{2}{c}{ Poland } & \multicolumn{2}{c}{ Portugal } & \multicolumn{2}{c}{ Turkey } \\
\hline Questionnaire & $\boldsymbol{M}$ & $\mathbf{S}_{\mathbf{x}}$ & $\boldsymbol{M}$ & $\mathbf{S}_{\mathbf{x}}$ & $\boldsymbol{M}$ & $\mathbf{S}_{\mathbf{x}}$ \\
\hline $\begin{array}{c}\text { Teacher Trainees' Sense of Professional } \\
\text { Agency in Practicum }\end{array}$ & 101.07 & 11.77 & 115.24 & 8.17 & 86 & 18.07 \\
\hline
\end{tabular}

As seen in Table 1, the mean scores differ in three countries. Table 2 displays to what degree this difference is statistically significant. In Table 2, Kruskal-Wallis H Test result explains that teacher trainees in Poland, Portugal, and Turkey differ in terms of their overall sense of professional agency in $\operatorname{practicum}\left(\chi^{2}=39.53, \mathrm{p}=.000<0.05\right)$.

Table 2. Kruskal-Wallis Test Results of "TTSPAP"

\begin{tabular}{ccccccc}
\hline & Groups & N & Mean Rank & $\chi^{2}$ & Df & p \\
\hline \multirow{2}{*}{$\begin{array}{c}\text { Teacher Trainees' Sense of } \\
\text { Professional Agency in Practicum }\end{array}$} & Poland & 27 & 48.57 & & & \\
\cline { 2 - 5 } & Portugal & 21 & 73.24 & 39.53 & 2 & $.000^{*}$ \\
\cline { 2 - 5 } & Turkey & 42 & 29.65 & & \\
\hline
\end{tabular}

$* \mathrm{p}<0.05$

According to Table 2, there is a statistically significant difference in the sense of agency in three countries. Mann-Whitney $U$ test results illustrate that teacher trainees in Portugal are statistically different from Turkish trainees $(\mathrm{U}=48.50, \mathrm{p}=.000<0.05)$. In a similar vein, teacher trainees in Poland differ from Turkish teacher trainees $(\mathrm{U}=294, \mathrm{p}=.001<0.05)$ and Portuguese teacher trainees $(\mathrm{U}=93.5$, $\mathrm{p}=.000<0.05)$ in terms of the practicum-based professional agency.

In addition to the total scores of TTSPAP questionnaire, the components of professional agency are examined separately as given in Table 3 . Table 3 presents the descriptive statistics for the questionnaire factors in each country. The mean scores were standardized according to the number of items per factor. 
Table 3. Descriptive Statistics for TTSPAP Questionnaire Factors

\begin{tabular}{ccccccc}
\hline & \multicolumn{2}{c}{ Poland } & \multicolumn{2}{c}{ Portugal } & \multicolumn{3}{c}{ Turkey } \\
\hline Questionnaire Factors & $\boldsymbol{M}$ & $\mathbf{S}_{\mathbf{x}}$ & $\boldsymbol{M}$ & $\mathbf{S}_{\mathbf{x}}$ & $\boldsymbol{M}_{\mathbf{x}}$ & $\mathbf{S}_{\mathbf{x}}$ \\
\hline 1. Collective Efficacy & 5.51 & 0.72 & 6.17 & 0.58 & 3.88 & 1.60 \\
\hline 2. Reflection & 5.88 & 0.77 & 6.75 & 0.30 & 5.77 & 0.82 \\
\hline 3. Positive Interdependence & 5.43 & 0.82 & 6.30 & 0.69 & 4.84 & 1.19 \\
\hline
\end{tabular}

As Table 3 outlines, the highest mean scores in three countries belong to the factor of "Reflection", which means that teacher trainees feel that they are more agentic in reflecting on their teaching practices and skills. The mean scores of Collective Efficacy, which requires collaboration and joint effort in practicum, are lower than other factors in Turkey $(M=3.88)$ and Portugal $(M=6.17)$. In regard to the Polish context, collective efficacy has higher mean than positive interdependence.

\subsubsection{Collective efficacy}

Collective efficacy is a factor which emphasizes the collaboration, cooperation, and encouragement in the community of practicum. Considering the items of "Collective Efficacy", it can be stated that all countries have the highest mean score in item 13 which elicits that teacher trainees can ask the teachers in practicum community for help. However, in Turkey, teacher trainees have some hesitations about getting inspiration from other colleagues in practicum $(M=3.48)$. Teacher trainees in Portugal $(M=5.81)$ and Poland $(M=5.11)$ expressed that other colleagues inspired them to improve their teaching, but this item has lower mean scores when compared to others in these countries.

Table 4. Descriptive Statistics for "Collective Efficacy"

\begin{tabular}{|c|c|c|c|c|c|c|}
\hline \multirow[b]{2}{*}{ Questionnaire Items } & \multicolumn{2}{|c|}{ Poland } & \multicolumn{2}{|c|}{ Portugal } & \multicolumn{2}{|c|}{ Turkey } \\
\hline & $M$ & $\mathbf{S}_{\mathbf{x}}$ & $M$ & $\mathbf{S}_{\mathbf{x}}$ & $M$ & $\mathbf{S}_{\mathbf{x}}$ \\
\hline $\begin{array}{l}\text { 1. My mentor teacher's and other English language teachers' } \\
\text { ideas inspire me to advance my own teaching. }\end{array}$ & 5.11 & 1.34 & 5.81 & 1.03 & 3.48 & 2.31 \\
\hline $\begin{array}{l}\text { 2. We are able to deal with challenging school situations } \\
\text { together with my mentor teacher. }\end{array}$ & 5.52 & 1.01 & 5.95 & 0.74 & 3.76 & 2.08 \\
\hline $\begin{array}{l}\text { 3. I'm able to utilize the critical feedback I get from the teacher } \\
\text { community (my mentor teacher and other English language } \\
\text { teachers) in my practicum school. }\end{array}$ & 5.41 & 1.05 & 6.42 & 0.60 & 3.76 & 2.07 \\
\hline $\begin{array}{l}\text { 4. I and the teacher community in my practicum school are able } \\
\text { to take care of our pupils together. }\end{array}$ & 5.67 & 1.21 & 6.48 & 0.68 & 3.95 & 1.90 \\
\hline $\begin{array}{l}\text { 5. I appreciate the fact that I and my mentor teacher have shared } \\
\text { rules of behaviour in facing the most challenging pupils. }\end{array}$ & 5.40 & 1.45 & 5.95 & 1.20 & 3.74 & 1.98 \\
\hline $\begin{array}{l}\text { 6. I can discuss even the difficult subjects in my teacher } \\
\text { community with my mentor teacher and other colleagues in my } \\
\text { practicum school. }\end{array}$ & 5.33 & 1.33 & 6.05 & 1.40 & 3.71 & 2.06 \\
\hline $\begin{array}{l}\text { 13. I'm not afraid to ask my mentor teacher and the other } \\
\text { teachers for help. }\end{array}$ & 6.15 & 1.03 & 6.52 & 0.87 & 4.79 & 2.10 \\
\hline
\end{tabular}


It can be seen in Table 4 that the mean scores vary across the countries. Table 5 statistically explains that these three countries differ significantly in terms of teacher trainees' sense of professional agency in "Collective Efficacy" $\left(\chi^{2}=37.74, \mathrm{p}=.000<0.05\right)$.

Table 5. Kruskal-Wallis Test Results of "Collective Efficacy"

\begin{tabular}{|c|c|c|c|c|c|c|}
\hline & Groups & $\mathbf{N}$ & Mean Rank & $\chi^{2}$ & df & $\mathbf{p}$ \\
\hline \multirow{3}{*}{ Collective Efficacy } & Poland & 27 & 52.87 & \multirow{3}{*}{37.740} & \multirow{3}{*}{2} & \multirow{3}{*}{$.000 *$} \\
\hline & Portugal & 21 & 68.71 & & & \\
\hline & Turkey & 42 & 28.65 & & & \\
\hline
\end{tabular}

Follow-up comparisons show that each two countries differ from each other in terms of the target construct. More specifically, Turkish teacher trainees' sense of collective efficacy is statistically different from those in Portugal $(U=74.50, p=.000<0.05)$ and those in Poland $(U=226, p=.000<0.05)$. In a similar vein, teacher trainees in Portuguese practicum schools significantly differ from the trainees in Poland in terms of the sense of collective efficacy ( $\mathrm{U}=141.5, \mathrm{p}=.003<0.05)$.

\subsubsection{Reflection}

According to the descriptive results in Table 6, the participants in all countries have a higher sense of agency in reflection. A majority of teacher trainees believe that they reflect on what they have experienced in practicum schools. The items that have the highest mean scores differ in three countries. In Turkey, teacher trainees put emphasis on the aspect of learning in practicum. Nonetheless, the mean score in item $8(M=4.50)$ is lower than the mean scores of other items in Turkey. In Portugal, all items have similarly high mean scores. That is, teacher trainees in Portugal feel highly agentic in reflection. As for the practicum context in Poland, in a similar way, there are some items that have relatively higher and lower mean values within the factor even if teacher trainees mostly agree with all the items. For example, item $11(M=6.30)$ that accentuates "learning in teaching" has the highest mean score. On the other hand, item $15(M=5.33)$ related to the estimation of future success in teaching has a lower mean score whereas most of teacher trainees in Poland agree with the expression given in this item.

Table 6. Descriptive Statistics for "Reflection"

\begin{tabular}{|c|c|c|c|c|c|c|}
\hline \multirow[b]{2}{*}{ Questionnaire Items } & \multicolumn{2}{|c|}{ Poland } & \multicolumn{2}{|c|}{ Portugal } & \multicolumn{2}{|c|}{ Turkey } \\
\hline & $M$ & $\mathbf{S}_{\mathbf{x}}$ & $M$ & $\mathbf{S}_{\mathbf{x}}$ & $M$ & $\mathbf{S}_{\mathbf{x}}$ \\
\hline 7. I'm planning to learn more about teaching. & 5.85 & 1.59 & 6.86 & 0.36 & 6.31 & .92 \\
\hline $\begin{array}{l}\text { 8. I'm willing to discuss my own work with my mentor } \\
\text { teacher and other teachers in the Practicum school. }\end{array}$ & 5.63 & 1.15 & 6.71 & 0.46 & 4.50 & 2.05 \\
\hline $\begin{array}{l}\text { 9. I'm able to create a nice atmosphere together with my } \\
\text { students in my practicum school. }\end{array}$ & 6.19 & 0.96 & 6.57 & 0.51 & 5.76 & 1.25 \\
\hline $\begin{array}{l}\text { 10. I'd like to understand student's ways of thinking and } \\
\text { acting better. }\end{array}$ & 6 & 1.14 & 6.71 & 0.64 & 6.14 & 1.05 \\
\hline 11. I think we can all learn something in a teaching situation. & 6.30 & 0.82 & 6.90 & 0.30 & 6.26 & 1.29 \\
\hline $\begin{array}{l}\text { 15. I regularly endeavour to estimate my success for my } \\
\text { future classrooms. }\end{array}$ & 5.33 & 1 & 6.76 & 0.46 & 5.64 & 1.28 \\
\hline
\end{tabular}


Despite the fact that participants have high mean scores in this factor, Table 7 explicates that there is a significant difference among three countries in terms of the professional agency in reflection $\left(\chi^{2}\right.$ $=31.481, \mathrm{p}=.000<0.05)$. In very broad terms, pre-service teachers in Poland, Portugal, and Turkey statistically differ in view of their sense of reflection in practicum.

Table 7. Kruskal-Wallis Test Results of "Reflection"

\begin{tabular}{|c|c|c|c|c|c|c|}
\hline & Groups & $\mathbf{N}$ & Mean Rank & $\chi^{2}$ & Df & $\mathbf{p}$ \\
\hline \multirow{3}{*}{ Reflection } & Poland & 27 & 38.98 & \multirow{3}{*}{31.481} & \multirow{3}{*}{2} & \multirow{3}{*}{$.000 *$} \\
\hline & Portugal & 21 & 73.29 & & & \\
\hline & Turkey & 42 & 35.80 & & & \\
\hline
\end{tabular}

$* \mathrm{p}<0.05$

Comparison tests show that teacher trainees' sense of agency in reflection in Portugal is statistically different from the agency in Poland $(\mathrm{U}=63, \mathrm{p}=.000<0.05)$ and Turkey $(\mathrm{U}=78, \mathrm{p}=.000<0.05)$ In Polish and Turkish practicum settings, teacher trainees have similar levels of professional agency in reflection.

\subsubsection{Positive interdependence}

Table 8 displays the descriptive statistics for positive interdependence in practicum. In Portugal, willingness to advance the teaching community $(M=6.57)$ and utilization of feedback from the pupils $(M=6.57)$ have the highest mean scores. In Poland and Turkey, adjusting teaching situations according to the differences has higher mean values. However, item 12 has lower mean scores in these three countries. This item highlights the trainees' endeavours to collaborate with others. In essence, teacher trainees believe that they are agentic in encouraging others for collaboration. Nevertheless, it has relatively lower mean scores in Portugal $(M=5.86)$, Poland $(M=4.85)$, and Turkey $(M=4.17)$ in comparison with other items.

Table 8. Descriptive Statistics for "Positive Interdependence"

\begin{tabular}{|c|c|c|c|c|c|c|}
\hline \multirow[b]{2}{*}{ Questionnaire Items } & \multicolumn{2}{|c|}{ Poland } & \multicolumn{2}{|c|}{ Portugal } & \multicolumn{2}{|c|}{ Turkey } \\
\hline & $M$ & $\mathbf{S}_{\mathbf{x}}$ & $M$ & $\mathbf{S}_{\mathbf{x}}$ & $M$ & $\mathbf{S}_{\mathbf{x}}$ \\
\hline $\begin{array}{l}\text { 12. I encourage my mentor teacher and other teacher } \\
\text { colleagues to collaborate. }\end{array}$ & 4.85 & 1.38 & 5.86 & 1.28 & 4.17 & 2.04 \\
\hline $\begin{array}{l}\text { 14. When planning my work I'm able to utilize the feedback } \\
\text { I get from my pupils in my practicum school. }\end{array}$ & 5.67 & 1.14 & 6.57 & 0.75 & 4.93 & 1.63 \\
\hline $\begin{array}{l}\text { 16. In the teacher community in my practicum school, we } \\
\text { encourage each other to develop. }\end{array}$ & 5.37 & 1.18 & 6 & 1.26 & 4.26 & 2.08 \\
\hline $\begin{array}{l}\text { 17. I'm willing to act in order to advance the best of our } \\
\text { entire teacher community in my practicum school. }\end{array}$ & 5.51 & 1.09 & 6.57 & 0.68 & 5.07 & 1.83 \\
\hline $\begin{array}{l}\text { 18. I can modify my teaching to adjust to different groups of } \\
\text { pupils in my practicum school. }\end{array}$ & 5.78 & 0.93 & 6.52 & 0.68 & 5.76 & 1.12 \\
\hline
\end{tabular}

The mean scores in "positive interdependence" show differences in the practicum settings of three countries. In this respect, Table 9 reports that these differences are statistically significant $\left(\chi^{2}=24.253\right.$, $\mathrm{p}=.000<0.05)$ in terms of the sense of positive interdependence. 
Table 9. Kruskal-Wallis Test Results of "Positive Interdependence"

\begin{tabular}{|c|c|c|c|c|c|c|}
\hline & Groups & $\mathbf{N}$ & Mean Rank & $\chi^{2}$ & df & $\mathbf{p}$ \\
\hline \multirow{3}{*}{ Positive Interdependence } & Poland & 27 & 44.96 & \multirow{3}{*}{24.253} & \multirow{3}{*}{2} & \multirow{3}{*}{$.000 *$} \\
\hline & Portugal & 21 & 68.60 & & & \\
\hline & Turkey & 42 & 34.30 & & & \\
\hline
\end{tabular}

Follow-up comparisons indicate that English language teacher trainees in Portugal are different from those in Poland $(\mathrm{U}=116.50, \mathrm{p}=.000<0.05)$ and Turkey $(\mathrm{U}=123, \mathrm{p}=.000<0.05)$ in terms of their sense of positive interdependence. In Poland and Turkey, teacher trainees have a similar level of positive interdependence agency in the practicum context.

\section{Discussion and Conclusion}

Teacher professional agency is viewed as one's intentions to take some actions which bring about changes in teaching communities (Pyhältö et al., 2011; Pyhältö et al., 2014; 2015; Vähäsantanen et al., 2009). Since the capacity of teachers to take actions largely depend on their different educational policy contexts (Toom et al., 2015), this study focuses attention on the comparison of three different practicum contexts as regards English language teacher trainees' sense of professional agency. The study findings holistically reveal that teacher trainees in three countries have a sense of professional agency in practicum, but the levels of agency vary across the countries. Likewise, teacher trainees' sense of agency differs within the factors of the target construct. According to these findings, Portuguese teacher trainees had the highest mean score (115.24) in the agency items in practicum. This finding is striking when the length of teacher training program is considered. As mentioned before, the teacher training program is pursued at MA level in Portugal and it lasts 3 semesters for the program "teaching young learners" or 4 semesters for the teaching programs for upper levels. On the contrary, Turkey has the lowest mean score (86) when compared to two countries despite the 4-year foreign language education. This finding shows that the development of professional agency should be promoted more in teacher education programs in Turkey. One suggestion might be to help Turkish teacher trainees to link theoretical education and real life classrooms at lower grades before they engage in practicum practices. Besides, they could be encouraged to take actions in teaching practices and make decisions about instructional processes so that they can develop more agentic behaviors. When the highest mean score of Portuguese teacher trainees is examined, one can conclude that at an MA level of teacher training program, teacher trainees may have more awareness on language teaching; therefore, they may have higher sense of agency. When teacher trainees' perceptions of reflection are examined, it is obviously seen that teacher trainees feel enthusiastic about reflecting on their teaching experiences during their practicum studies. Likewise, it could be deduced that teacher trainees benefited from the first stage of the practicum practice, which was attending and observing the lessons and keeping a reflective journal and discussing their experiences with their teacher trainers. Such an implementation may promote teacher trainees' reflective perspectives. At this point, the significance of 'reflection' in teacher education programs should be highlighted and it can be suggested that reflective practice of teacher trainees should be developed during BA studies so that teacher trainees continue to pursue reflection when they become a professional. This finding also confirms the findings of the study which reveals the effectiveness of guided reflection journals teacher trainees wrote during practicum teaching (Degago, 2007). When the constructs in 'reflection' item are examined separately, two distinctive findings are found. Turkish trainees yield they are willing to learn more about teaching (the mean score of this item is 6.31). This 
displays that although teacher trainees in Turkey have a 4-year teacher training at the Faculty of Education, they are open to learning more about teaching at the final stage of their study. However, in the construct related to collaboration with mentor teachers and other colleagues, Turkish teacher trainees may have some hesitations in being so willing to discuss their own work with them. To this end, it can be suggested that from trainees' perspective, teacher trainees should be empowered to reflect on their teaching practices and then encouraged to discuss it with mentor teachers. Finally, from the mentor teachers' perspective, the responsible teachers might get observation and supervision trainings to help teacher trainees with effective mentoring strategies.

Portuguese teacher trainees display higher levels of mean scores at 'collective efficacy', which refers mostly to the collaborative work between the colleagues or collegial support between teacher trainees and mentor teachers at the workplace; and 'positive interdependence', which refers to organizational moves to plan future actions or improve the teaching environment. This result might stem from the MA level practicum studies of the Portuguese teacher trainees and the existence of more senior teacher trainees in the group. The age level and experience might ease the process of collaborative work, mutual support and organizational moves. Among the three countries, Turkey has the lowest mean score in 'positive interdependence'. Therefore, the teacher educators in Turkey should focus on the quality of teacher education programs, and provide teacher trainees with mutual support and encourage them to take part in organizational moves in teaching practices. Turkish and Polish groups, however, show similar results at collective efficacy and positive interdependence as both groups are at similar age levels and are engaged in similar practicum contexts. It could be argued that more collective practices are required in teacher education programs in both countries, which is only pursued at the final year of the study. Furthermore, it can be deduced that teacher trainees need more inspiration from teacher educators, mentor teachers and other colleagues in improving their teaching skills. Finally, the results of the construct 'I encourage my mentor teacher and other teacher colleagues to collaborate' in the attribute of positive interdependence indicate that three countries have low mean scores, which might be explained by the inexperience of teacher trainees and not having future time perspectives in terms of professional learning.

Priorly, it is stated that two parameters at the community level, 'collective efficacy and positive interdependence' contribute to the parameter, 'reflection', at the individual level (Pietarinen et al., 2016). This study proves that teacher trainees may have a sense of professional agency at community level in different degrees, and they may feel more agentic at individual level. As Atay (2006) suggested that through collaboration, both prospective teachers and experienced teachers would become more reflective; therefore, teacher educators should tap into the collegial interaction between mentor teachers and teacher trainees. Similarly, congruent with Alger's (2006) view that signifies the cooperating teacher, supervisor or a colleague who would examine the strengths and weaknesses of a lesson, teacher educators should consolidate a mutually supportive learning environment for practitioners; otherwise, as Alger (2006) suggests, critical reflection done by the teacher trainees would remain scarce.

To conclude, this study confirmed that high levels of collective efficacy, positive interdependence and reflectivity lead to agentic teacher trainees during the practicum experience, however, the levels of the sense of agency in particular components might differ due to the contextual varieties. Although these three factors are complementary components that shape the agentic behaviours of the practitioner, one component might outweigh the others. This study revealed that teacher trainees in three countries felt more agentic when they were engaged in reflective practice. Though teacher trainees showed fairly high levels at the parameters of collective efficacy and positive interdependence, the results displayed that the sense of agency may be enhanced at these areas. Of the three countries, Portuguese practicum context displayed the highest levels of agency at three components. However, Polish and Turkish teachers showed similar levels of agency at the components of reflection and positive interdependence. The 
results might vary due to the nature of practicum studies as Portuguese practitioners studied at the MA level. The difference at collective efficacy and positive interdependence levels across countries might result from the distance or sincerity levels between the mentor teachers and teacher trainees, which was beyond the scope of this study.

These issues highlight the importance of continuous professional development for mentor teachers to enhance their mentoring skills. Likewise, teacher trainees should be given opportunities to develop an understanding of professional agency during their pre-service teacher education, and teacher educators should design practicum teaching in a way that teacher trainees could enhance their capacity to operate with the professional agency. Despite the fact that the current study provides an overall description and comparison of the professional agency in practicum, it has some limitations in terms of elaborating on the differences among the countries. For instance, it is necessary to collect longitudinal data from the stakeholders to observe how teacher trainees' professional agency is shaped in years, and to investigate the reasons why teacher trainees differ in the components of agency. As a further study, observation of the practicum practices of the teacher trainees could be implemented and teacher educator perspective could also be integrated. Another limitation of the study is the sample size. Since there are some varieties in practicum teaching across the countries, the number of participants showed differences in these three countries. Following studies may pay attention to the inclusion of more practicum settings in different countries to display the sense of professional agency from broader perspectives.

\section{Acknowledgements}

This article is produced as a part of the Erasmus + project titled ILTERG "International Language Teacher Education Research Group" (no: KA203-035295) funded by the Turkish National Agency. The data were collected from Gazi University, Pomeranian University and the University of Evora as the partners of the project. This study was also presented in ILTERG Conference in Antalya in May, 2019. We would like to thank Dorota Werbińska and Lili Cavalheiro for their support in data collection in Poland and Portugal and elaboration of the Polish and Portuguese practicum contexts.

\section{References}

Akbari, R. (2007). Reflections on reflection: A critical appraisal of reflective practices in L2 teacher education. System: An International Journal of Educational Technology and Applied Linguistics, $35(2), 192-220$.

Alger, C. (2006). 'What went well, what didn't go so well': Growth of reflection in pre-service teachers. Reflective Practice, 7(3), 287-301.

Atay, D. (2006). Teachers' professional development: Partnerships in research. Teaching English as a Second or Foreign Language, 10(2), 1-15.

Bakkenes, T. I., Vermunt, J. D., Wubbels, T., \& Imants, J. G. (2006). Teachers' perceptions of the school as a context for workplace learning. In Education research in the public interest. Washington: American Educational Research Association.

Clement, M., \& Vandenberghe, R. (2000). Teachers' professional development: A solitary or collegial (ad)venture? Teaching and Teacher Education, 16, 81-101.

Cohen, L., Manion, L., \& Morrison, K. (2007). Research methods in education (6th ed.). Oxon: Routledge. 
Degago, A. T. (2007). Using reflective journals to enhance impoverished practicum placements: A case in teacher education in Ethiopia. Teaching Education, 18(4), 343-356. doi: $10.1080 / 10476210701687633$

De Vries, S., Jansen, E., \& Van de Grift, W. (2013). Profiling teachers' continuing professional development and the relation with their beliefs about learning and teaching. Teaching and Teacher Education, 33, 78-89.

Edwards, A. (2007). Relational agency in professional practice: A CHAT analysis. Actio: An International Journal of Human Activity Theory, 1, 1-17.

Eröz-Tuğa, B. (2012). Reflective feedback sessions using video recordings. ELT Journal, 67(2), 175183.

Eteläpelto, A., Vähäsantanen, K., Hökkä P., \& Paloniemi S. (2013). What is agency? Conceptualizing professional agency at work. Educational Research Review, 10, 45-65. doi.org/10.1016/j.edurev.2013.05.001

Field, A. (2013). Discovering statistics using IBM SPSS statistics (4th ed.). London: Sage Publications.

Fraenkel, J. R., Wallen, N. E., \& Hyun, H. H. (2012). How to design and evaluate research in education (8th ed.). New York: McGraw-Hill.

Han, J., \& Yin, H. (2016). Teacher motivation: Definition, research development and implications for teachers, Cogent Education, 3(1). doi:10.1080/2331186X.2016.1217819

Hinton, P. R., McMurray, I., \& Brownlow, C. (2014). SPSS explained (2nd ed.). London, UK: Routledge.

Hoekstra, A., Beijard, D., Brekelmans, D., \& Korthagen, F. (2007). Experienced teachers' informal learning from classroom teaching. Teachers and Teaching: Theory and Practice, 13(2), 189-206.

Husu, J., \& Toom, A. (2010). Opettaminen neuvotteluna - oppiminen osallisuutena: opettajuus demokraattisena professiona [Teaching as negotiation - Learning as participation: The democratic profession of teaching]. In A. Kallioniemi, A. Toom, M. Ubani, \& H. Linnansaari (Eds.), Akateeminen luokanopettajakoulutus: 30 vuotta teoriaa, käytäntöä ja maistereita [Academic class teacher education: 30 years of theory, practice and masters] (pp. 133-147). Research in Educational Sciences 52. Turku: Finnish Educational Research Association.

Husu, J., Toom, A., \& Patrikainen, S. (2008). Guided reflection as a means to demonstrate and develop student teachers' reflective competencies. Reflective Practice, 9(1), 37-51.

Kwakman, K. (2003). Factors affecting teachers' participation in professional learning activities. Teaching and Teacher Education, 19, 149-170.

Lipponen, L., \& Kumpulainen, K. (2011). Acting as accountable authors: Creating interactional spaces for agency work in teacher education. Teacher and Teacher Education, 27, 812-819. doi:10.1016/j.tate.2011.01.001

Meirink, J.A., Meijer, P.C., Verloop, N, Bergen, T.C.M. (2009). Understanding teacher learning in secondary education: the relations of teacher activities to changed beliefs about teaching and learning. Teaching and Teaching Education, 25(1), 89-100. doi:10.1016/j.tate.2008.07.003

Organisation for Economic Co-operation and Development [OECD] (2018). Education at a Glance 2018: OECD Indicators. Paris: OECD Publishing. http://dx.doi.org/10.1787/eag-2018-en

Pietarinen, J., Pyhältö, K., \& Soini, T. (2016). Teacher's professional agency-a relational approach to teacher learning. Learning: Research and Practice, 2(2), 112-129. 
Pomaki, G., DeLongis, A., Frey, D., Short, K., \& Woehrle, T. (2010). When the going gets tough: Direct, buffering and indirect effects of social support on turnover intention. Teaching and Teacher Education, 26(6), 1340-1346. doi:10.1016/j.tate.2010.03.007

Pyhältö, K., Pietarinen, J., \& Soini, T. (2014). Comprehensive school teachers' professional agency in large-scale educational change. Journal of Educational Change, 15, 303-325.

Pyhältö, K., Pietarinen, J., \& Soini, T. (2015). Teachers' professional agency and learning - from adaption to active modification in teacher community. Teachers and Teaching: Theory and Practice., 21(7), 811-830.

Pyhältö, K., Pietarinen, J., Soini, T. (2012). Do comprehensive school teachers perceive themselves as active professional agents in school reforms? Journal of Educational Change. 13(1). 95-116.

Pyhältö, K., Soini, T., \& Pietarinen, J. (2011). A systemic perspective on school reform. Journal of Educational Administration, 49(1), 46-61.

Sachs, J. (2003). The activist teaching profession. Buckingham, Philadelphia: Open University Press.

Skaalvik, E. M., \& Skaalvik, S. (2011). Teachers' feeling of belonging, exhaustion, and job satisfaction: The role of school goal structure and value consonance. Anxiety, Stress and Coping, 24, 369-385.

Soini, T., Pietarinen, J., \& Pyhältö, K. (2016). What if teachers learn in the classroom? Teacher Development, 20(3), 380-397.

Susoy, Z. (2015). Watch your teaching: A reflection strategy for EFL pre-service teachers through video recordings, Procedia-Social and Behavioural Sciences, 199, 163-171.

Toom, A., Pyhältö, K., \& Rust, F. (2015). Teachers' professional agency in contradictory times, Teachers and Teaching, 21(6), 615-623. doi:10.1080/13540602.2015.1044334

Turnbull, M. (2005). Student teacher professional agency in the practicum. Asia-Pacific Journal of Teacher Education, 33, 195-208.

Vähäsantanen, K., Saarinen, J., \& Eteläpelto, A. (2009). Between school and working life: Vocational teachers' agency in boundary-crossing settings. International Journal of Educational Research, 48, 395-404.

Zeichner, K., \& Conklin, H. G. (2010). Teacher education programs as sites for teacher preparation. In M. Cochran-Smith, S. Feiman-Nemser, \& J. D. McIntyre (Eds.), Handbook of research on teacher education. Enduring questions in changing contexts (pp. 269-289). New York, NY: Routledge, Taylor \& Francis Group. 


\section{İngiliz dili eğitimi stajında mesleki eylemlilik anlayışı: Polonya, Portekiz ve Türkiye bağlamlarının karşılaştırılması}

\section{$\ddot{O} \mathbf{z}$}

Öğretmen eylemliliği, bir öğretmenin öğretme ortamında değişiklik meydana getiren kararları ve eylemleri alma yükümlülüğü ve yeteneğini tanımlayan kavramdır. Staj eğitimi, öğretmen adaylarının hem teorik hem de pratik öğretme deneyimlerini zenginleştirdiği ilk yerdir. Bu nedenle bu eğitim öğretmen adaylarının mesleki eylemliliğ̈ini şekillendirmede önemli bir rol oynamaktadır. Staj eğitimine ve farklı eğitim ortamlarına vurgu yapan bu çalışma, Polonya, Portekiz ve Türkiye'deki İngilizce öğretmeni adaylarının stajdaki mesleki eylemlilik anlayışını betimlemeyi amaçlamaktadır. Ek olarak, bu çalışma mesleki eylemlilik açısından üç staj ortamını karşılaştırmaya çalışmaktadır. Temel bulgular, üç ülkede de öğretmen adaylarının mesleki eylemlilik anlayışına sahip olduklarını fakat eylemlilik düzeylerinin değişiklik gösterdiğini belirtmektedir. Eylemliliğin dinamikleri düşünüldüğünde öğretmen adaylarının yansıtmada kendilerini daha fazla eyleme dönük hissettiği söylenebilir. Türkiye ve Polonya staj bağlamları, yansıtma ve olumlu dayanışma öğeleri açısından benzerlik göstermektedir. Buna rağmen, bütünsel bir bakış açısı ile üç ülke de mesleki eylemlilik anlayışında anlamlı olarak farklılaşmaktadır.

Anahtar sözcükler: öğretmen adaylarının eylemliliği; staj; mesleki eylemliliğin karşılaştıılması

\section{AUTHOR BIODATA}

Burçak Yılmaz Yakışık holds her PhD in English Language Teaching, Gazi University. Her research areas cover learner variables, teacher training, teacher identity, sociocultural theory and assessment.

Fatıma Nur Fişne is currently pursuing her PhD in English Language Teaching Department at Gazi University. Her research interests include English language assessment and evaluation, teaching English to young learners, and English language teacher education.

Gonca Yangın Ekşi works as a professor at Gazi University ELT Department. Her research interests are teacher training, technology and language learning, culture and curriculum development. 